Article

\title{
The Gatekeeper within: Early Modern English Architectural Tropes of Female Consent
}

\author{
Elisa Oh \\ Department of English, Howard University, Washington, DC 20059, USA; eoh@howard.edu
}

Received: 2 December 2018; Accepted: 20 February 2019; Published: 28 February 2019

check for updates

\begin{abstract}
This essay maps out a constellation of early modern English feminine gatekeeper tropes that represent female sexual consent and imagine a gendered Cartesian dualism. This trope's inherent mind-body divide grants the female subject's mind a greater measure of rationality and autonomy from the body than other early modern discourses of feminine virtue, such as humoralism. However, it can also undercut feminine agency in self-regulation by placing all the responsibility and blame on the woman's mind in cases of sexual harrassment and assault. Hadrian Dorrell's Avisa, Shakespeare's Lucrece, Thomas Heywood's Jane Shore, and Christopher Marlowe's Hero represent a spectrum of feminine mental complicity in extramarital sex, yet their mental "gatekeepers" are all suspected of failure. Shakespeare's Juliet and Cressida literalize this gatekeeper trope and render it a material allegory when they negotiate with male suitors at literal portals on stage, a window and a chamber door. Examining the extraordinary pressures put on feminine "gatekeeper" minds in early modern texts allows us to discern contemporary willingness to blame the victims of sexual assault.
\end{abstract}

Keywords: early modern women; chastity; rape; consent; architecture; Shakespeare

Rude man, 'tis vain thy damsel to commend

To keeper's trust: their wits should them defend.

Who, without fear, is chaste, is chaste in sooth:

Who, because means want, doeth not, she doth.

Though thou her body guard, her mind is stained:

Nor, lest she will, can any be restrained.

Nor canst by watching keep her mind from sin:

All being shut out, th'adulterer is within. (Marlowe 2000, p. 53)

Not only do the opening lines of Christopher Marlowe's translation of Ovid's Amores Book III, Elegy IV evoke a familiar early modern patriarchal interest in policing a woman's chastity, but this passage also draws attention to the challenge of controlling feminine mental transgression "within". The "rude" or unlearned man guards the virtue of his wife by physically locking her up in a house and entrusting her dangerously porous body to a male "keeper", who can watch her every moment as an extension of her husband's gaze. However, the male speaker claims that the jealous husband will always be impotent when it comes to controlling the real agent here-the woman's mind-because apparently only her independent "wits" can self-regulate the licit and illicit entrances to her home and body, not her husband's authority. ${ }^{1}$ Marlowe's expression of this perceived limit to male power renders the

1 This elegy provides further examples of this problem with contrasting classical anecdotes: In stone and iron walls Danae shut,/Came forth a mother, though a maid there put./Penelope, though no watch looked unto her,/Was not defiled by any gallant wooer" (Marlowe 2000, p. 54). 
house at once a metonym and an allegory for the woman's body: traditional early modern gender roles closely associate a woman with the domestic structure in which she works and resides. Furthermore, by allegorical extension, the actions of that building's inhabitant and "gatekeeper" correspond to the agency of a feminine mind in safeguarding the limens of her body. This pervasive trope posits a gendered mind-body divide that grants the woman an empowering intellectual agency over her body and at the same time undercuts the reliability of that sovereign gatekeeper mind when it regulates sexual consent. This expectation of constant feminine mental vigilance coexists with constant suspicion of the mind's failure in the early modern English discourse of illicit sex and, in fact, continues to haunt us today in the twenty-first century.

Figuring a gatekeeper mind that regulates traffic through the portals of her body's architecture allows representation of widely different levels of feminine consent to sexual activity. This personified feminine mind might energetically bar the door to adulterous penetration, make a conflicted but calculated decision to open the door due to negative pressures, or throw open the door with gleeful willingness to men other than her husband. This trope's inherent mind-body divide grants the female subject's mind a greater measure of autonomy from the body and rationality than other early modern discourses of feminine virtue, such as humoralism, which would assert that a woman's moral and mental failings arise from the inherent weakness of her body. However, rendering the body as inanimate architecture in this trope places all the expectation-and blame-on the woman's mind. Marlowe's lines above emphasize three times the expectation that the woman's independent mind can and should be the active guardian of her physical chastity ("their wits should them defend"; "who without fear, is chaste, is chaste in sooth"; and "lest she will"). Yet intertwined with this claim of supreme mental self-control, the elegy sows doubt four times that the mental gatekeeper is secretly corrupt ("Who, because means want, doeth not, she doth"; "her mind is stained"; "Nor canst by watching keep her mind from $\sin ^{\prime}$; and "th'adulterer is within"). This essay will argue that, regardless of different levels of sexual consent, this female architectural gatekeeper of chastity trope always encodes an inescapable double bind: the guardian mind is always expected to be on duty, and it is always suspected of being inadequate in its duty. The result of this ideology is that feminine intellectual culpability is built into every extramarital sexual transgression in which the woman ends up alive.

The feminine gatekeeper tropes in the attempted seductions of Hadrian Dorrell's Avisa and Christopher Marlowe's Hero represent opposite ends of a spectrum of female consent; the former is absolutely mentally and physically impenetrable, while the latter turns out to be a "traitor" within the fort who is complicit in letting the enemy in. In contrast, Shakespeare's Lucrece and Thomas Heywood's Jane Shore occupy a more morally complex middle ground in the representation of their sexual consent: after being threatened and coerced mentally, both give tacit consent to unwanted sex. Though the men are the aggressors, the women accept guilt for it, reproducing the ideology that their gatekeeper minds failed in their guard duty. Shakespeare's Juliet and Cressida negotiate sexual consent on stage at a literal window and doorway, and the relation between the actors playing these characters and their material thresholds infuse the seduction scenes with the contradictions of the mentally responsible and mentally complicit gatekeeper metaphor. Despite her inviting words and actions in the balcony scene, Juliet maintains her chastity by keeping her suitor outside of her window until after their wedding vows. Cressida too depicts a defensive feminine mental gatekeeper at a literal doorway as she delays the consummation of her affair with Troilus, and her mind assumes the guilt for her decision to become Diomedes' mistress.

Though it is tempting to relegate such culturally pervasive misogyny about female sexual consent to the distant past, identifying this early modern discourse serves to help us see it more perceptively today. The recent Senate Judiciary Committee's hearing questioning of Dr. Christine Blasey Ford about her alleged sexual assault by then-Supreme-Court-nominee Brett Kavanaugh provides evidence that the dominant discourse of expecting a woman's mind to be constantly vigilant yet ever faulty as a gatekeeper of her body is still circulating and impacting the way women and men respond to sexual assaults today. 
The gatekeeper trope for female sexual consent imagines a gendered mind-body divide in which the mind functions as an independent entity separate from the properties of the body. However, it is worth noting that the literary texts examined in this essay pre-date by 35 to 50 years the publication of René Descartes' influential articulation of mind-body dualism in his Discourse on the Method (1637), Meditations on First Philosophy (1641), and Principles of Philosophy (1644). It is not my intention to claim an earlier date for the tenets of Descartes' cogito but rather to use the term "mind-body divide" to indicate a nascent dualism in the early modern ideology of the gendered self that imagined an autonomous governing mind, spirit, or soul for women. ${ }^{2}$ Amy Greenstadt traces a similar intellectual tradition of imagining the body and soul as separate entities back to Saint Augustine's The City of God against the Pagans (c. 427): "Augustine argued that an act of rape did not necessarily destroy a woman's chastity because sexual purity was a condition of the will rather than the body—a formulation echoed in the [early modern] law's definition of this crime as a violation of the woman's body against her will" (Greenstadt 2009, pp. x-xi).

Sarah E. Johnson's study of representations of the gendered body-soul divide in early modern English drama finds that the standard configuration of the relationship comprised a male soul governing a female body. The four paradigms for the early modern women's mind-body dynamic that Johnson defines - the puppeteer and puppet; tamer and tamed; ghost and haunted; and observer and spectacle-locate traditionally masculine qualities such as rationality, judgment, and rightful sovereignty in the "mind" part of each dichotomy. However, Johnson claims that this gendered hierarchy was, in fact, often manipulated to enable feminine agency. "If conventional gendering of the soul-body hierarchy served as a patriarchal tool for women's subordination (as it explicitly did), it carries equal potential to promote empowering ideas of women" (5). This essay introduces another paradigm for representing a woman's mind and body in the trope of a mental gatekeeper who is responsible for guarding the body's chastity, which is represented as portals in an architectural structure. This trope is distinct from those delineated by Johnson because the female body is represented as an inanimate architectural object that is not a passive tool or instrument to be animated by the masculine mind nor the site of unreliable senses, passions, change, or volition. Hence, the gatekeeper trope genders the governing mind female and attributes moral success or failure at preserving chastity to that gatekeeper mind alone. ${ }^{3}$

This pervasive literary trope that figures a feminine mind as a gatekeeper of the architectural portals of her body's chastity differs significantly from the competing contemporary early modern discourse of humoralism, which assumes that the inferior qualities of a woman's mind are intrinsically formed and influenced by the make-up of her body. The early modern discourse of humoralism understood the qualities of men and women's minds and personalities to be influenced by the balance of their four physiological humors. ${ }^{4}$ Women's colder and wetter humors meant that they possessed inferior intellectual and moral decision-making capacity than men and displayed mental, sexual, and verbal incontinence as natural manifestations of their porous bodies or "leaky vessels", to use Gail Kern Paster's apt term for "the female body's material expressiveness-its production of fluids"(Paster 1987, p. 44). Women's tendency to "overflow" with tears, menstrual blood, breast milk, and, in Paster's examples from city comedy, urine is synonymous with the way women's words, thoughts, and actions also apparently overflow proper boundaries. ${ }^{5}$ Paster concludes that

2 For an intellectual history of the body and soul relationship from Plato, Christian, and medieval English theology through seventeenth-century English body and soul dialogues, see Rosalie Osmond, who asserts that in Jacobean drama women were rarely associated with the soul and only "where they are viewed alone, apart from the context of their relationship with men" (Osmund 1990, p. 167).

3 In Johnson's incisive analysis of The Lady's Tragedy, the woman's ghost/mind is separated from her inanimate body by suicide and portrays traditionally masculine traits of self-control and virtue, but the body that this feminine ghost/mind "directs and spurs to action" (Johnson 2014, p. 113) is that of a living man.

4 See Laqueur (1992), Schoenfeldt (2000), Paster (1993), and Maclean (1999).

5 On early modern women's garrulity and cultural attempts to regulate their speech, see Patricia Parker's argument that "[e]xcesses of speech and diseases of the tongue [were] characterized as 'feminine'" (Parker 1989, p. 450). See also Gowing 
"representations of the female body as a leaking vessel display that body as beyond the control of the female subject, and thus as threatening the acquisitive norms of the family and its maintenance of status and power"(Paster 1987, p. 49 my emphasis). Peter Stallybrass invokes the Bakhtinian difference between the "finished, completed, and closed" classical body and the "unfinished" grotesque body that "outgrows itself, transgresses its own limits" (Stallybrass 1986, p. 124); he claims that sixteenth-century conduct book writers assumed that women's bodies were "naturally 'grotesque'" and therefore were in need of constant surveillance of "the mouth, chastity, the threshold of the house" (Stallybrass 1986, p. 126).

In addition to setting the gatekeeper trope in opposition to the discourse of humoralism, this concept must also be set alongside early modern discourses of architecture as it informed gendered privacy and subjectivity. Critical studies relating architectural enclosure and early modern female subjectivity have centered on the advent of the "closet" and other increasingly private spaces in sixteenth- and seventeenth-century domestic architecture. ${ }^{6}$ Lisa Jardine notes the utter privacy of a woman's closet, which was embedded within other concentric chambers of increasing privacy and shows how this place of independent solitude is a reified "space" of feminine subjectivity (Jardine 1994, p. 150). Sasha Roberts posits that "[i]n what we might term the gendering of private space, women were specifically encouraged to identify their closets and bedchambers as chaste spaces" (Roberts 1998, p. 37). Similarly, Georgiana Ziegler traces the development of domestic architecture and the corresponding idea of mental and physical privacy for women. She sees Hamlet's intrusions on Gertrude and Ophelia, Tarquin's rape, Othello's murder, and Iachimo's spying in women's private chambers as constituting “a rape of [the woman's] private space” (Ziegler 1990, p. 73). However, Ziegler equates the private space inside the closet with both the feminine mind and body: "In all these works the woman's chamber has represented her 'self': both her physical body and mental/spiritual nature" (Ziegler 1990, p. 87).

In contrast, the female body-as-architecture trope that I consider here presents a divide between a woman's mind and body; the woman's gatekeeper mind is figured as an active, decision-making entity who inhabits the walls of her body, but is also distinguished from them. Jessica C. Murphy argues that early modern English prescriptive works urge women to practice an active, intellectual form of obedience when they regulate their own virtue, and, in order to do so, they must "analyze behavioral prescriptions critically because their proper performance necessitates interpretation on their part" (Murphy 2015, p. 12). The gatekeeper trope focuses attention on how the feminine mind performs that very analysis and independent interpretation of contemporary behavioral prescriptions about regulating an individual's chastity. However, the literary examples that follow reveal both the empowerment and the drawbacks of the expectation for women to possess rational minds that govern their bodies: not only must they constantly perform analytical intellectual self-regulation, but their

(1996) work on early modern women's litigation for sexual slander as well as Spargo (1944), Boose (1991), and Underdown (1985a, 1985b) on scolds' bridles and other shaming practices.

6 For more on the relationship between early modern subjectivity, sense of privacy, and architectural space, see Mimi Yiu's reading and beautiful contextualization of Gertrude's "closet" (Yiu 2015, pp. 97-135) and Alan Stewart's analysis of Angel Day's The English Secretorie (1592). (Stewart 1995, pp. 76-100) Referring to contemporary diaries, Retha Warnicke describes the mental and physical experience of domestic privacy for women in the early seventeenth century. (Warnicke 1993, pp. 123-40) Ronald Huebert compares male and female opportunities for privacy, such as periods of solitary reading, and concludes that a woman tended to experience privacy as something "furtive and surreptitious" while a man found privacy to be "simply his due, and ... therefore supported and guaranteed by the members of his household" (Huebert 2001, p. 51). Sasha Roberts studies the material culture of privacy: keys, locks, and who held the keys to which rooms in an early modern household (Roberts 1998, pp. 52-58). In his study of the literal and metaphoric aesthetics of "the closet", James Knowles notes that " $[\mathrm{t}]$ he closet generated much anxiety, largely because of its ambivalent status and the uncertainty which shrouds its relations and transactions" (Knowles 1998, p. 10). Patricia Fumerton explores the history of banqueting house architecture as illustrative of the Tudor-Stuart search for increasingly private spaces (Fumerton 1991, pp. 111-67). She suggests, however, that the sense of an "achieved identity of privacy" may have been "forever elusive, unlocatable" (Fumerton 1991, p. 130). Mary Hazard also provides a stimulating analysis of the political implications embedded in the architectural spaces in the houses built by aspiring Elizabethan courtiers (Hazard 2000, pp. 143-72). 
minds must also bear the constant suspicion and blame for any consensual or nonconsensual sexual transgression that occurs.

The early modern figuring of the human body as an architectural structure has roots in medieval English literature. Anne Lancashire traces the history of the emblematic castle and notes its three major purposes as "[1] the castle of virtue (or of a virtue) or of mansoul (the soul as contained within a man's body) or of the world assaulted ... by vice; [2] the castle of female chastity ... and [3] the castle of hell, or of pride, lechery, or other vices" (Lancashire 1984, p. 223). These emblems illuminate the tendency to gender the inhabitant soul masculine. The concept of "mansoul" articulates the distinction between body and mind in the way that Spenser's Alma (soul) inhabits the Castle of Temperance, which has architectural features that correspond to the parts of the body. (Spenser 1977, pp. 247-58) The "castle" of female chastity appears as early as the Digby saint's play Mary Magdalene, circa 1480-1520 (Lancashire 1984, p. 225), and it is featured in Philip Sidney's pageant performed before Queen Elizabeth in 1581 in which the virgin queen's gallery was designated the "Castle or Fortress of Perfect Beauty" and was assailed by the "four Foster children of Desire" (Sidney 1989, pp. 299-310).

Figuring the female body as a house and the vagina as a door that could be open, closed, or locked was a common early modern metaphor for chastity. Patricia Parker notes that in (Crooke 1615), Helkiah Crooke's medical anatomy refers to "'the outward privity or lap' of a woman as a 'cleft' which like a 'doore' might be 'opened' or 'shut' - a sense of the 'close' or of something closeted behind a 'doore' which pervades medical as well as popular references to this secret place” (Parker 1994, p. 114). Just as explicitly, Cocledemoy's bawdy song in John Marston's The Dutch Courtesan conflates a woman's body with a door:

Maids in your night-rails,

Look well to your light-; [tails]

Keep close your locks,

And keep down your smocks;

Keep a broad eye,

And a close thigh. (Marston 1997)

The aposiopesis - or rhetorical choice to break off in mid-sentence-evokes female genitals through the suggestion of rhyme, and although "locks" ostensibly refers to the doors of the maids' bedrooms, the locks become a vivid metaphor for the accessibility of a maid's bodily orifice when they are juxtaposed with the unmentioned "tails", "smocks", and open or "close" thighs. ${ }^{\text {The song's }}$ admonitory vigilance is addressed to the women's mind, the imagined inner guardian who opens or closes her outer boundaries. ${ }^{8}$ This metaphor does not question the stable structure of the building or female body, which are both necessarily porous by nature; rather, the mind within the body is the sole controlling factor in the regulation of her chastity.

Hadrian Dorrell's Willobie His Avisa (1594) presents an example of an ideally chaste female mental gatekeeper who successfully defends her body from suitors who attempt to enter her walled city. In verse dialogues between a virtuous wife, Avisa, and her would-be seducers, Avisa has a response for every man who urges her to commit adultery, including this young soldier who deploys the familiar siege metaphor:

7 Of "close", the OED reads, "Of closed or shut up state or condition, and its results ... with the secondary associations of concealment, exclusiveness, narrowness, etc". Just as a "close[d] door" denotes spatial "concealment", "exclusiveness", and privacy, a "close thigh" refers to the physical, sexual exclusiveness required of women by a patriarchal society.

8 Similarly, in Marston's Antonio and Mellida (1602), Rosaline teases Mellida with a bawdy joke calling Galeazzo, a potential suitor, "one that will besiege thy maidenhead,/Enter thy walls, i'faith, sweet Mellida,/If that thy flankers be not cannonproof" (Marston 1991, p. 15). In this metaphor, the "flankers" or protective forts are equivalent to Mellida's thighs, with a pun on "flanks". 
“The Second Temptation of AVISA, after her marriage by Ruffians, Roysters, young Gentlemen, and lustie Captaines, wich all shee quickly cuts off"' (De Luna 1970, p. 153).

[Caveleiro:] To plant a siege, and yet depart,

Before the towne be yeelded quite,

It kils a martiall mans hart,

That can not brooke such high despite,

Then say you yea, or say you no,

I'le scale your wals, before I go. (De Luna 1970, p. 160)

[AVISA:] The wisest Captaine now and then,

When that he feeles his foe too strong;

Retires betime to save his men,

That grow but weake, if seege be long;

From this assault you may retire,

You shall not reach, that you require.

I hate to feede you with delaies,

As others doe, that meane to yeeld,

You spend in vaine your strong assaies,

To win the towne, or gaine the feeld;

No Captaine did, nor ever shall,

Set ladder here, to skale the wall. (De Luna 1970, p. 161) ${ }^{9}$

Despite his martial language and threats to "scale [her] wals", her gatekeeper mind effectively dissuades him from wasting more of his time attempting to gain entrance to her fort merely by asserting that she will never allow him to "reach, that you require" or "[s]et ladder here, to skale the wall". In this scenario, it is insidiously represented as a contest of minds or wills rather than one of actual physical force. This portrait of ideal feminine self-regulation still includes the antifeminist doubt that any woman could be constantly mentally vigilant in defense of her chastity. Even the perfectly impenetrable Avisa admits that "others" resist and still "meane to yeeld". This reference to less chaste women attributes Avisa's own success and other women's failure to guard their chastity to the mind's rational choices rather than to the body's unreliability.

Christopher Marlowe's Hero and Leander (1598) presents Hero as one of those rational, autonomous, yet morally inconsistent feminine gatekeepers who "meene to yeeld" her body's chastity. Like Avisa, this poem represents sexual consummation as the result of a military siege on a walled fortress, but this version of the woman-as-walled-fort metaphor credits the woman's mind with greater culpability because of a secret complicity with the "enemy" and ultimate enjoyment of surrender. Disturbingly, the siege represents a gendered power struggle in Hero and Leander's foreplay, which is a combative negotiation of her sexual consent:

Yet ever as he greedily assayed

To touch those dainties, she the harpy played,

And every limb did as a soldier stout

Defend the fort, and keep the foeman out. (Marlowe 2000, pp. 90-91) 
At first, Hero seems to be "defending her fort" as vigorously as Avisa, but then her mental gatekeeper betrays her "duty" by making a "truce" with her "enemy", who breaks the truce and begins embracing and kissing her again. Moral hypocrisy then appears in the "thoughts" of the gatekeeper mind:

Treason was in her thought,

And cunningly to yield herself she sought.

Seeming not won, yet won she was at length,

In such wars women use but half their strength.

Leander now, like the Theban Hercules,

Entered the orchard of the Hesperides. (Marlowe 2000, p. 91)

Hero's mind, like the traitor who is supposed to be guarding a besieged city, consciously, "cunningly" plots to help the enemy invade the fort. While she "seems not won" and fends off his advances, she secretly wants and intends to yield. The description of the final physical penetration does not continue the siege metaphor, which would involve sacking, burning, and raping; instead it transforms the female body into a fruitful garden, another walled structure made to provide sensory pleasure and nourishment. ${ }^{10}$

The need to contain women's sexuality in a patriarchal society does not depend solely on the porousness of the fort's walls-it also depends on how faithfully or traitorously the women's minds defended those walls. Marlowe's assertion that "in such wars women use but half their strength" is at once a male fantasy and a male fear about women's complicity in illicit sex acts, and it emphasizes the epistemological problem that one can never know whether a woman used all her strength, half her strength, or no strength at all to fend off rapists or potential extramarital lovers. Each of these defensive siege metaphors attributes positive agency to a woman's rational, independent, self-regulating mind, but at the same time, they expect that gatekeeper mind to exert constant vigilance and always suspect that she is not trying hard enough. The specter of the mind that could defend her chastity but secretly chooses not to do so haunts all the other constructions of a feminine mind that governs her body.

In between extreme examples of perfect gatekeeping like chaste Avisa and unreliable gatekeeping like Hero, other early modern female characters who are victims of rape or sexual harassment, like Shakespeare's Lucrece and Heywood's Jane Shore, make calculated and pragmatic, though unwilling, decisions to allow men to cross their bodily thresholds. Though their intentions may be virtuous and their actions the result of dire necessity, these two narratives explore the disquieting moral limits of moments when women's sovereign minds could decide to allow illicit and unwanted penetration of their bodies. If extenuating circumstances could force the feminine gatekeeper mind to give unwilling consent to the man's entrance into her body, could the virtue of her mind stay wholly separate from her violated body? Jessica C. Murphy's analysis of the "paradox of chastity" shows that early modern prescriptive texts construct it as "at once weak and strong, passive and active, obvious and hidden" (Murphy 2015, p. 14). Her reading of Juan Vives' extreme and unsympathetic position on female chastity underscores the double bind in which early modern rape victims could find themselves: "According to Vives, a woman who loses her virginity always consents to do so, even when it seems most obvious that her consent is absent. Sexual violation is therefore rarely a violation at all; it is something for which the woman has offered her tacit consent" (Murphy 2015, p. 19).

10 Cristina Malcolmson asserts that "Marvell's use of the imagery of enclosure cannot be understood apart from its relation to gender: in the Cavalier poems ... enclosure is used as a metaphor for marriage ... The bodies of women become analogous to and emblematic of the property whose ownership and government were in dispute in England during this period. The imagery of the enclosed garden of England and the enclosed garden of the chaste but generative wife blend in new ways as the literature of the Civil War contests over the nature of a proper 'husbandman' for the country" (Malcolmson 1994, p. 252). Images of a woman's body as a fruitful but enclosed garden are also found throughout the Song of Songs. 
Shakespeare's Lucrece decides to submit silently to Tarquin after he threatens to kill her and put her in the bed of a servant, whom he would tell her husband was her secret lover. His penetration through a series of rooms and doors to reach Lucrece graphically mirrors the rape itself.

The locks between her chamber and his will,

Each one by him enforc'd retires his ward;

But as they open they all rate his ill,

Which drives the creeping thief to some regard.

The threshold grates the door to have him heard ...

As each unwilling portal yields him way. (Shakespeare 1974, p. 1726)

These resistant personified locks, creaking and grating against his entrance, anticipate Lucrece's initial reproaches and refusals when faced with her rapist and continued mental resistance to him. Though each portal is "unwilling", Tarquin still forces them to yield before him. When he comes to the last barrier, her chamber door itself, however, the resistance is insignificant:

Now is he come unto the chamber door

That shuts him from the heaven of his thought,

Which with a yielding latch, and with no more,

Hath barr'd him from the blessed thing he sought...

This said, his guilty hand pluck'd up the latch,

And with his knee the door he opens wide. (Shakespeare 1974, p. 1726)

The last latch is now "yielding", just as Lucrece ceases to struggle against him when she realizes that she must stay alive in order to preserve her reputation. In these passages, the term "yield", which often indicates a woman's unambiguous sexual consent, sustains other possible meanings: (1.) an inanimate object is giving way to physical force; (2.) a person's body is surrendering because it has lost a physical battle; or (3.) a person's mind is ceasing to resist as a rational decision in response to persuasion, threat, or argumentation. This uncertainty about what kind of "yielding" Lucrece did parallels the early modern uncertainty about whether women's coerced tacit consent to illicit sex was the same thing as the guilty consent of complicity.

The house's personified barriers parallel the mistress's physical barriers, but, unlike Ziegler, I would argue that the penetration of the domestic architectural space does not represent a rape of the woman's mind and body. On the contrary, Shakespeare goes to great lengths to distinguish between Lucrece's innocent mind and her violated body. When announcing the rape to Collatine, Lucrece insists that her pure soul is trapped inside a polluted body: "Though my gross blood be stain'd with this abuse,/Immaculate and spotless is my mind;/That was not forc'd, that never was inclin'd/To accessory yieldings, but still pure/Doth in her poison'd closet yet endure" (Shakespeare 1974, p. 1740), and Shakespeare's narratorial voice also appropriates this metaphor when describing Lucrece's suicide. ${ }^{11}$ Her knife "unsheath[s]" her soul from its "polluted prison" (Shakespeare 1974, p. 1741). The gathered lords tried to claim that "[h]er body's stain her mind untainted clears" (Shakespeare 1974, p. 1741), but Lucrece realizes that her level of mental complicity will always be unknowable and therefore doubtful: “'No, no,' quoth she, 'no dame hereafter living/By my excuse shall claim excuse's giving" (Shakespeare 1974, p. 1741). Supposedly, if she accepts this reprieve from guilt, all future generations of

11 The Lady in Milton's Comus (1634) similarly insists on a complete separation between the chastity of her mind and of her body. After being brought to Comus's feast of temptation and bound to an enchanted chair, she says defiantly, "Fool do not boast,/Thou canst not touch the freedom of my mind/With all thy charms, although this corporeal rind/Thou hast immanacled" (Milton 1968, p. 209). 
women will be able to claim falsely that the illicit sex they engaged in willingly was innocent because they were forced.

As much as her suicide seems to claim that her "stain' $d$ " body will inevitably infect her mind with sin, the narrative of her pragmatic mental decision to survive and public revelation of her rape demonstrate the absolute separation between mind and body. Unfortunately, her audience could not be certain of her lack of mental consent because of the ambiguity about whether tacit consent could ever be innocent. By committing suicide, Lucrece confirms the complete independence of her "pure" mind from her body. Despite her audience's perception of her body's integrity being inescapably "polluted", her mind retains the resolve and self-control to exonerate herself in words and deeds. ${ }^{12}$ Lucrece's case reinforces the mental gatekeeper trope's insistence that the independent female mind carries all the responsibility for the body's chastity and takes all the blame when it is lost. Jocelyn Catty's study of rape in early modern drama reveals another facet to the injustice of expecting the victim of sexual assault to bear intellectual responsibility for her own violation: "rape as chastity test puts great emphasis on the female art of dissuasion. In spite of the numerous examples in which women are clearly powerless to prevent their rape, it is generally defined implicitly as a woman's failure of eloquence ... [T]his emphasis also implies that if a woman cannot dissuade a man from rape, her chastity is questionable" (Catty 1999, p. 100).

In Thomas Heywood's 1 Edward IV (1599), Jane Shore also makes a conflicted but rational decision to submit to the pressure of a powerful man to engage in illicit sex. Like Lucrece, she is a faithful wife who does not want to betray her husband, and her articulation of how she regulated her chastity uses the feminine gatekeeper trope to express her internalized guilt and accept her moral failure. Jane's decision to become the king's mistress is fraught with more culpability than Lucrece's because Jane endures the unwelcome sex but does not commit suicide afterward. When Jane encounters her husband at court after her transformation from wife to courtesan and he accuses her of not being a widow, maid, or wife, she describes her decision to "yield":

I must confess, I yielded up my fort,

Wherein lay all the riches of my joy;

But yet, sweet Shore, before I yielded it,

I did endure the long'st and greatest siege

That ever batter'd on poor chastity.

And but to him that did assault the same,

For ever it had been invincible. (Heywood 1966)

She chooses to submit to the king's forced entrance to her "fort" and to continued illicit sex as his mistress. She accepts the privileges that come with being a royal mistress but tries to offset this moral failing by using her power at court to help worthy "suitors" attain justice.

In her explanation to her husband, she tries to mitigate the guilt of her mental complicity with her "enemy" by describing the king's combination of persuasion and coercion as "the long'st and greatest siege" any woman ever endured. Unlike the married woman speaker in Willobie His Avisa, Jane is unable to defend herself against the rhetorical threats and "attacks" of her seducer. Though the king begins with flattery and offers of money and social prestige, he-like Tarquin-finally lets Jane know that he can exercise complete physical and social power over her.

12 Sarah E. Johnson posits that "Shakespeare's Lucrece ... has internalized the cultural association of bodily chastity with spiritual integrity to the extent that she resolves to destroy her violated body as the only means to free her 'pure mind' from contamination" (Johnson 2014, pp. 90-91). I suggest in contrast that the suicide demonstrates her entire mind-body divide and the primacy and agency of her mind. Amy Greenstadt reads Lucrece's rape as a metaphor for the threat to the integrity of the author's intention when published and/or misinterpreted. "In submitting their textual bodies to publication, both Lucrece and Shakespeare attempt to perpetuate their wills while performing acts of submission mandated by the social roles they inhabit" (Greenstadt 2009, p. 80). 
KING: But, leaving this our enigmatic talk,

Thou must, sweet Jane, repair unto the Court.

His tongue entreats, controls the greatest peer:

His hand plights love, a royal sceptre holds;

And his heart he hath confirm'd thy good,

Which may not, must not, shall not be withstood.

JANE: If you enforce me, I have nought to say;

But wish I had not liv'd to see this day. (Heywood 1966)

Jane's chastity has not been successfully besieged by unruly passions but by the absolute power of a monarch over her life as a city craftsman's wife. The king hovers between the roles of seducer and rapist when he gives up the fiction of wooing and threatens to use his official power, with which he can command all the nobles and territory of England, to harm Jane rather than beg for her love. In this way, the king is able to "enforce" his will upon Jane as he would "enforce" a law and possess her body sexually through force just as he would have legal and military authority to occupy any castle in his realm. By putting pressure on the woman's mind with this threat, the king has achieved access to her "fort". Jane's moral position between her chastity and loyalty to her husband on one hand and her fear of her king on the other complicates the stereotypical portrait of a consenting whore who would let anyone through her "gates".

By employing literal stage thresholds that evoke the same connotations as the pervasive feminine gatekeeper trope examined above, Shakespeare allows the theater audience to witness spatial and material representations of the conflicting factors that influence a woman's sexual consent. Scenes of seduction set at actual windows and doors transform the actor playing the "gatekeeper" woman into the allegorical feminine mind negotiating the defense of her chastity in Romeo and Juliet and Troilus and Cressida. Each scene dramatizes a woman's sexual negotiation at metaphorically significant architectural threshold that is fraught with doubt, indecision, and moral danger. These liminal moments enact varying levels of feminine mental consent, responsibility, and expected culpability in initiating sexual relations outside socially sanctioned marriage.

Romeo and Juliet's movements in relation to the balcony itself in the "balcony scene" turn the literal window into an allegory of negotiating female sexual consent in Romeo and Juliet. When the audience witnesses Juliet enter "above", they are already primed by this literary trope to see the window as an architectural portal to a feminine inner sanctum in which erotic transactions occur. Romeo has already penetrated outer barriers of the Capulet's noble household to get here:

JULIET: How camest thou hither, tell me, and wherefore?

The orchard walls are high and hard to climb,

And the place death, considering who thou art,

If any of my kinsmen find thee here.

ROMEO: With love's light wings did I o'erperch these walls,

For stony limits cannot hold love out,

And what love can do, that love dares attempt;

Therefore thy kinsmen are no stop to me. (Shakespeare 1974, p. 1068)

This image places the woman, chamber, and her virginity in the center of concentric rings of architectural fortifications, defended by family loyalty and death threats to any intruder. However, Romeo's difficulty in climbing those stony walls is rewarded by reaching the fruitful "orchard" on the inside and overhearing Juliet's apparently private expression of desire for him. Romeo's comment 
about his own boldness at infiltrating the Capulet stronghold holds an unsettling suggestion of Tarqin-like rape- " what love can do, that love dares attempt" - but the entire encounter at the balcony remains virtuous because Romeo never makes an attempt to enter the window by force, bribes, or deceit, and she insists that she will be his only if "thy bent of love be honorable,/Thy purpose marriage" (Shakespeare 1974, p. 1069). Unlike Tarquin, Leander, and King Edward, Romeo's only request for "satisfaction" is the verbal exchange of "love's faithful vow" (Shakespeare 1974, p. 1069).

Juliet physically enters and exits three times during this scene, and this material, visible movement of her body in and out of her window enacts her inner mental "gatekeeper's" emotional gestures of trust, attraction, and caution as they vacillate between intimacy and restraint. The Nurse, the supposed guardian of Juliet's chastity, calls to her repeatedly to withdraw inside the chaste confines of her bedchamber, causing Juliet's first two exits. However, Juliet herself concludes the interaction with her third exit after, "A thousand times good night!" (Shakespeare 1974, p. 1069). The literal removal of her physical and verbal availability at the window signals Juliet's chaste decorum of self-regulation, despite her extravagant professions of "My true-love passion" (Shakespeare 1974, p. 1069) and impetuous act of calling Romeo back to her like a pet bird. Only after the wedding vows at Friar Lawrence's cell will Romeo "climb a bird's nest" (Shakespeare 1974, p. 1074) on a ladder fetched by the Nurse to enter her window and consummate their marriage. ${ }^{13}$ Juliet regulates her chastity by obviating all parental ratification of the "too rash, too unadvis'd, too sudden" (Shakespeare 1974, p. 1069) contract, but she does obey the religious imperative of keeping Romeo on the outside of the window until the marriage vows have been made before God, the ultimate source of patriarchal prescription against premarital sex.

Shakespeare again exploits the connotations of a literal architectural threshold to depict the feminine mind's rational misgivings when considering sexual consent in Troilus and Cressida. Although at the turn of the seventeenth century the character of Cressida had come to epitomize a faithless woman and traitor, her tough talk about self-protection and her lengthy hesitation before allowing Troilus to enter her chamber door portray a female gatekeeper mind's vigilance and intellectual misgivings about initiating a sexual relationship. From early in the play, Cressida expresses wariness of the risks of love, unlike the careless, flirtatious Helen. Cressida's self-defensive attitude appears as she banters with Pandarus. He comments on her biting wit that "[o]ne knows not at what ward you lie" (Shakespeare 1998, p. 153), and she responds, "Upon my back, to defend my belly; upon my wit, to defend my wiles; upon my secrecy, to defend mine honesty; my mask to defend my beauty; and you, to defend all these; and at all these wards I lie, at a thousand watches" (Shakespeare 1998, p. 153). Though Pandarus uses the term "ward" to refer to "a defensive posture or movement"(OED $\left.\mathrm{sb}^{2} 8 \mathrm{a}\right)$ taught to fencers for parrying blows, two other early modern definitions aptly correspond to Cressida's mental guard duty at the gate of her body's castle: "the action or function of a watchman ... observation for discovering the approach of danger" (OED sb $\left.{ }^{2} 1\right)$ and "[i]n a fortress ... [ $t$ ] he portion of the defences entrusted to a particular officer or division of the garrison ... a guarded entrance" (OED $\mathrm{sb}^{2} 14 \mathrm{a}-\mathrm{b}$.) Cressida's reply claims she stands ready to engage in constant, diverse, mental and physical

13 All's Well That Ends Well features a more sordid version of Juliet's balcony scene: Helena introduces the trope of the beseiged castle of chastity when she tells Diana's mother, "The count he woos your daughter,/Lays down his wanton seige before her beauty,/Resolv'd to carry her" (Shakespeare 1974, p. 528). To effect the bed-trick, Diana must consent to his private entrance to her house and body. She indicates, "[w] hen midnight comes, knock at my chamber window;/I'll order take my mother shall not hear ... When you have conquer'd my yet maiden bed,/Remain there but an hour, nor speak to me" (Shakespeare 1974, p. 530). In Much Ado About Nothing, Don John leads Claudio and Don Pedro to believe that Hero cheated on the eve of her wedding by "talk[ing] with a ruffian at her chamber window" (Shakespeare 1974, p. 352). One reason Hero is blamed so readily are the powerful, preexisting sexual resonances associated with men being seduced by women through windows. See Michel de Montaigne's travel journal account of seeing prostitutes in Rome advertising themselves through windows and inviting men in for business (Montaigne 1983) and Barbara Lewalski's account of an anonymous male annotator of Rachel Speght's A Mouzell for Melastomus who wrote, "Her thoughts manie times looke out at her Eyes, \& come fourth in her wordes. Besides you may if you please, enter into her minde by hir bodyes gate; and have them all, sutch as they are" (Speght 1996, p. 103). Moments after Bianca is seen at an upper window watching a parade in Thomas Middleton's Women Beware Women, the Duke begins to lust after her and plot her rape. (Middleton 1968) 
action to keep her body, mind, chastity, and beauty safe. When she says that it is "at all these wards I lie", it sounds like her mental gatekeeper is never off duty but standing "watch" day and night.

At Cressida's door, the crucial threshold between public and private, chastity and sexual consummation, each of her delays and doubts represents her mental gatekeeper defending her chastity by detaining Troilus outside the architectural limens that stands for her sexual consent to enter her body. Troilus sees her door as the portal to paradise when he complains to Pandarus that "I stalk about her door/Like a strange soul upon the Stygian banks/Staying for waftage. O be thou my Charon,/And give me swift transportance to those fields/where I may wallow in the lily beds/Propos'd for the deserver!" (Shakespeare 1998, p. 228) Cressida, however, expresses her mind's rational caution in her multiple physical withdrawals, which are apparent in Pandarus's speech:

Come, come, what need you blush? Shame's a baby. Here she is now;

swear the oaths not to her that you have sworn to me.-What, are you

gone again?-You must be watched ere you be made tame, must you?

Come your ways, come your ways: and you draw backward we'll put

you i'th'fills. (Shakespeare 1998, pp. 230-31)

Pandarus describes and dictates Cressida's stage directions, indicating that she hangs back when first brought face to face with her potential lover. She also wears a veil, a traditional sign of modesty.

Despite her seemingly direct invitation, “Will you walk in, my lord?" (Shakespeare 1998, p. 232), Cressida still delays Troilus's entrance into her chamber with verbal pauses and alludes to her reservations about accepting a lover:

TROILUS: O Cressid, how often have I wished me thus.

CRESSIDA: Wished, my lord? The gods grant-O my lord-

TROIL: What should they grant? What makes this pretty abruption? What too

curious dreg espies my sweet lady in the fountain of our love?

CRESS: More dregs than water, if my fears have eyes.

TROIL: Fears make devils out of cherubins; they never see truly.

CRESS: Blind fear, that seeing reason leads, finds safer footing than blind

reason stumbling without fear. To fear the worst oft cures the worse. (Shakespeare 1998, pp. 232-233)

Cressida breaks off in the middle of asking the gods to grant Troilus's wish or perhaps a private wish of her own. Interrupting herself shows her cautious mind self-editing her words and striving to preserve a measure of privacy. She does not allow Troilus to belittle her fears or redefine them as mere misperception. Rather, she defends the perspicuity of her mind's "seeing reason" and justifies her intentional pessimism of fearing the worst.

Cressida's subsequent confession of her love for Troilus betrays a progressive loss of mental self-regulation as she alternates between guarded suspicion-“If I confess much you will play the tyrant" (Shakespeare 1998, p. 235)—and inadvertent confession-“"My thoughts are like unbridled children, grown/Too headstrong for their mother.-See, we fools! /Why have I blabb'd?" (Shakespeare 1998, pp. 235-236). She knows full well that "things won are done" (Shakespeare 1998, p. 155), meaning that, if her mental gatekeeper allows Troilus into her chamber, it will be both the end of her ongoing social power of being wooed and the penetration of her body. So the longer she keeps Troilus outside her door, the longer his love and her physical and emotional independence will last. Cressida makes one last attempt to leave Troilus's presence and avoid the imminent penetration of her 
chamber, "Where is my wit? / I would be gone. I speak I know not what" (Shakespeare 1998, p. 237), but Pandarus intervenes and provides the momentum that impels them through the door and into bed.

Knowing and wary, Cressida renders the work of her mental gatekeeper visible on stage in her delays at the door to her chamber, where she enacts an allegory of feminine sexual consent alloyed with doubt, caution, and regret. In this assertion of Cressida's self-awareness and mental control in her own seduction and destiny, I take issue with Grace Tiffany's argument that Cressida chooses "self-erasure" and willingly participates in the misogynistic creation of her identity as "sluttish spoils" of men. (Tiffany 1993) On the contrary, Cressida's verbal and physical reticence demonstrates her intellectual consideration of the social consequences of this decision. Shakespeare appropriates the important distinction between a woman's mind and body inherent in the female body-as-architecture trope in order to locate the source of a woman's sexual consent in her independent "gatekeeper" mind rather than in the inconstant humoral physiology of the body itself.

Debate about the role of a rational, governing, and self-guarding mind in women's sexual consent continues today, particularly in relation to survivors of sexual violence. The recent confirmation hearings for Supreme Court Justice Brett Kavanaugh (4 September-5 October 2018) featured the testimony of Dr. Christine Blasey Ford, who recounted a traumatic assault on her body allegedly by Kavanaugh as a teenager; however, the mixed reception of her incomplete memories by the American public and her questioners demonstrate on one hand an intense sympathy for her trauma and on the other a skepticism about her access to and mental control over the factual truth of her own bodily experience (Stolberg and Fandos 2018). Her critics demanded the performance of more complete and precise memory by a gatekeeper mind that was asked and expected to recall minutely the time, place, date, names, words, and actions of other people in the house, how she got home, and additional details about the circumstances that surrounded the alleged attack 36 years ago (Jett 2018). These critiques comprise the rhetorical fallacy known as a faulty analogy; they claim that her uncertainty about contextual facts is evidence of uncertainty that the assault happened at all and/or uncertainty about the identity of the person who committed it. Despite her own professional training in the ways memory functions inconsistently during and after a traumatic experience as well as reference to these science-based facts of neurology by several of her questioners, Dr. Blasey Ford herself apologized several times for not remembering more facts and repeatedly expressed a wish to be more "helpful" with producing specific information. (Bloomberg Government 2018) These responses evince a sense of responsibility and guilt for moments when her mind was apparently not properly watching and controlling the events surrounding an assault that was so violent that she feared for her life. Clearly, a feminine mental gatekeeper who is unreasonably expected to be constantly guarding her own physical boundaries and yet is always doubted to be attending reliably to her self-regulation remains a harmful trope that still haunts us today.

Funding: This research received no external funding.

Acknowledgments: I am indebted to Esmé Bieberly, Erin Murphy, and Rachel Watson for their thoughtful commentary on earlier drafts of this essay. I am also grateful to this Special Issue's editors, Jessica C. Murphy and Kris McAbee. Finally, this essay benefited greatly from the incisive feedback contributed by Humanities' outside reader.

Conflicts of Interest: The author declares no conflict of interest.

\section{References}

Boose, Lynda E. 1991. Scolding Brides and Bridling Scolds: Taming the Woman's Unruly Member. Shakespeare Quarterly 42: 179-213. [CrossRef]

Bloomberg Government. 2018. Kavanaugh Hearing: Transcript. Washington Post, September 28. Available online: https: / www.washingtonpost.com/news/national/wp/2018/09/27/kavanaugh-hearing-transcript/

?noredirect=on\&utm_term $=. d 92$ cb6518fdd (accessed on 15 February 2019).

Catty, Jocelyn. 1999. Writing Rape, Writing Women in Early Modern England: Unbridled Speech. Basingstoke: Macmillan, New York: St. Martin's Press. 
Crooke, Helkiah. 1615. Microcosmographia: A Description of the Body of Man. London: n.p.

De Luna, Barbara N. 1970. The Queen Declined: An Interpretation of Willobie His Avisa with the Text of the Original Edition. Oxford: Oxford at the Clarendon Press.

Fumerton, Patricia. 1991. Cultural Aesthetics: Renaissance Literature and the Practice of Social Ornament. Chicago: U of Chicago P.

Gowing, Laura. 1996. Domestic Dangers: Women, Words, and Sex in Early Modern London. Oxford: Clarendon Press. Greenstadt, Amy. 2009. Rape and the Rise of the Author: Gendering Intention in Early Modern England. Farnham and Burlington: Ashgate.

Hazard, Mary. 2000. Elizabethan Silent Language. Lincoln: U of Nebraska P.

Heywood, Thomas. 1966. 1 Edward IV. Shakespeare Society of London Publications. Nendeln: Kraus Reprint Ltd. Huebert, Ronald. 2001. The Gendering of Privacy. The Seventeenth Century 16: 37-67. [CrossRef] [PubMed] Jardine, Lisa. 1994. Reading Shakespeare Historically. New York: Routledge.

Jett, Jennifer. 2018. Right and Left React to the Kavanaugh-Blasey Hearings. New York Times, September 28. Available online: https:/ /www.nytimes.com/2018/09/28/us/politics/kavanaugh-blasey-hearing-reactions.html (accessed on 15 February 2019).

Johnson, Sarah E. 2014. Staging Women and the Soul-Body Dynamic in Early Modern England.. Farnham: Ashgate.

Knowles, James. 1998. 'Infinite Riches in a Little Room': Marlowe and the Aesthetics of the Closet. In Renaissance Configurations: Voices/Bodies/Spaces, 1580-1690. Edited by Gordon McMullen. Houndsmill: Macmillan, pp. 3-29.

Lancashire, Anne. 1984. The Emblematic Castle in Shakespeare and Middleton. In Mirror Up to Shakespeare. Edited by Jack Cooper Gray. Toronto: U of Toronto P, pp. 223-41.

Laqueur, Thomas. 1992. Making Sex: Body and Gender from the Greeks to Freud. Cambridge: Harvard UP.

Maclean, Ian. 1999. The Notion of Woman in Medicine, Anatomy, and Physiology. In Feminism and Renaissance Studies. Edited by Lorna Hutson. Oxford: Oxford UP.

Malcolmson, Cristina. 1994. The Garden Enclosed/The Woman Enclosed: Marvell and the Cavalier Poets. In Enclosure Acts: Sexuality, Property, and Culture in Early Modern England. Edited by Richard Burt and John M. Archer. Ithaca: Cornell UP, pp. 251-69.

Marlowe, Christopher. 2000. Christopher Marlowe: Complete Poems. Edited by Mark T. Burnett. London: J.M. Dent. Marston, John. 1991. Antonio and Mellida. Edited by W. Reavley Gair. Manchester: Manchester UP.

Marston, John. 1997. The Malcontent and Other Plays. Edited by Keith Sturgess. Oxford: Oxford UP.

Middleton, Thomas. 1968. Women Beware Women. A New Mermaid Edition. Edited by Roma Gill. New York: Hill and Wang.

Milton, John. 1968. Comus. Complete Shorter Poems. Edited by John Carey. London: Longman.

Montaigne, Michel. 1983. Montaigne's Travel Journal. Translated by Donald M. Frame. San Francisco: North Point Press.

Murphy, Jessica C. 2015. Virtuous Necessity: Conduct Literature and the Making of the Virtuous Woman in Early Modern England. Ann Arbor: University of Michigan Press.

Osmund, Rosalie. 1990. Mutual Accusation: Seventeenth-Century Body and Soul Dialogues in Their Literary and Theological Contexts. Toronto: University of Toronto Press.

Parker, Patricia. 1989. On the Tongue: Cross Gendering, Effeminacy, and the Art of Words. Style 23: 445-65.

Parker, Patricia. 1994. Othello and Hamlet: Dilation, Spying, and the 'Secret Place' of Woman. In Shakespeare Reread: The Texts in New Contexts. Edited by Russ McDonald. Ithaca: Cornell UP, pp. 105-46.

Paster, Gail Kern. 1987. Leaky Vessels: The Incontinent Women of City Comedy. Renaissance Drama 18: 43-65. [CrossRef]

Paster, Gail Kern. 1993. The Body Embarrassed: Drama and the Disciplines of Shame in Early Modern England. Ithaca: Cornell UP.

Roberts, Sasha. 1998. Shakespeare 'creepes into the womens closets about bedtime': Women reading in a room of their own. In Renaissance Configurations. Edited by Gordon McMullen. Houndsmill: Macmillan, pp. 30-63.

Schoenfeldt, Michael C. 2000. Bodies and Selves in Early Modern England: Physiology and Inwardness in Spenser, Shakespeare, Herbert, and Milton. Cambridge: Cambridge UP.

Shakespeare, William. 1974. The Riverside Shakespeare. Boston: Houghton Mifflin.

Shakespeare, William. 1998. Troilus and Cressida. The Arden Shakespeare. Edited by David Bevington. London: Thomson Learning. 
Sidney, Philip. 1989. Sir Philip Sidney: A Critical Edition of the Major Works. Edited by Katherine Duncan-Jon. Oxford: Oxford UP, pp. 299-310.

Spargo, John Webster. 1944. Juridical Folklore in England Illustrated by the Cucking-Stool. Durham: Duke UP.

Speght, Rachel. 1996. The Polemics and Poems of Rachel Speght. Edited by Barbara Kiefer Lewalski. New York: Oxford UP.

Spenser, Edmund. 1977. The Faerie Queene. Edited by Albert Charles Hamilton. London: Longman.

Stallybrass, Peter. 1986. Patriarchal Territories: The Body Enclosed. In Rewriting the Renaissance. Edited by Margaret Ferguson, Maureen Quilligan and Nancy Vickers. Chicago: U of Chicago P.

Stewart, Alan. 1995. The early modern closet discovered. Representations 50: 76-100. [CrossRef]

Stolberg, Sheryl Gay, and Nicholas Fandos. 2018. Brett Kavanaugh and Christine Blasey Ford Duel with Tears and Fury. New York Times, September 27. Available online: https:/ /www.nytimes.com/2018/09/27/us/politics/ brett-kavanaugh-confirmation-hearings.html(accessed on 15 February 2019).

Tiffany, Grace. 1993. Not Saying No: Female Self-Erasure in Troilus and Cressida. Texas Studies in Literature and Language 35: 44-56.

Underdown, David. 1985a. Revel, Riot, and Rebellion: Popular Politics and Culture in England 1603-1660. Oxford: Clarendon Press.

Underdown, David. 1985b. The Taming of the Scold: The Enforcement of Patriarchal Authority in Early Modern England. In Order and Disorder in Early Modern England. Edited by Anthony Fletcher and John Stevenson. Cambridge: Cambridge UP.

Warnicke, Retha. 1993. Private and Public: The Boundaries of Women's Lives in Early Stuart England. In Privileging Gender in Early Modern England. Edited by Jean Brink. Kirksville: Sixteenth Century Journal Publishers, pp. 123-40.

Yiu, Mimi. 2015. Architectural Involutions: Writing, Staging, and Building Space, c. 1435-1650. Evanston: Northwestern UP.

Ziegler, Georgianna. 1990. My lady's chamber: female space, female chastity in Shakespeare. Textual Practice 4: 73-90. [CrossRef]

(C) 2019 by the author. Licensee MDPI, Basel, Switzerland. This article is an open access article distributed under the terms and conditions of the Creative Commons Attribution (CC BY) license (http://creativecommons.org/licenses/by/4.0/). 